\title{
Atla Association Update
}

Prepared by Brenda Bailey-Hainer, Executive Director

Each year at Atla Annual, I provide an update on the finances and accomplishments of Atla during the previous year. This year my allotted timeslot was very short, so an expanded version of this presentation was published in the July 2021 Atla Newsletter.

\section{TRANSITION TO FULLY DISTRIBUTED WORKPLACE}

In the December 2020 Atla Newsletter, I announced that Atla would be moving to a fully distributed workplace when the lease for our office space at $300 \mathrm{~S}$. Wacker Drive in downtown Chicago expired at the end of February 2021. We completed that transition in early 2021.

Two years prior to the end of the lease, our information systems staff began moving all of our data and processes to the cloud. The biggest challenge related to our move was emptying out the old office under COVID-19 restrictions, and this turned out to take six months. On the final day of the move, it took 19 hours and a team of 12 movers to actually complete the final piece of the move. I want to recognize the work of Maria Stanton, Director of Production, and Jim Butler, Director of Information Systems, who managed the transition.

Many of you visited our old office as part of participating in committee or board meetings. All of us, including the staff, have many fond memories of our time together in that location. Our new office is really just a 183-square-foot room designed to store our permanent records and to receive and process our mail. The Atla staff now work full time from their homes, continuing to provide members and customers with the same high level of support. But the true heart and soul of Atla isn't about a physical space. It lies in the members and staff and our connections with one another.

\section{ATLA FINANCES}

Last fiscal year, which ended August 31, 2020, was financially stable for Atla. Despite our fears about the impact of the pandemic on Atla revenue, in the end we had only a slight downturn in revenue. As always, our budget for the year was breakeven, with $\$ 8,516,285$ 
projected for both revenue and expense. Although at the end of the year our revenue came in slightly less at $\$ 7,619,127$, our expenses also were less than anticipated at \$7,549,240.

Atla's primary source of revenue continued to be royalties from the research tools we create (93\%). Income generated from Member Programs Department activities was related to the conference and fees for services such as hosting e-journals for other organizations (3\%). Interest from investments and other miscellaneous income accounted for the other $4 \%$ of overall revenue.

On the expense side, the largest portion was used for staff and technology to produce Atla research tools (60\%). However, a significant amount of Atla's expenses is focused on fulfillment of the mission and organizational ends - last year this was $23 \%$. That includes funding committee work, open-access publishing, Member Programs staff, and professional development opportunities for our members, such as Atla Annual and our ongoing webinar series. Board meetings and other governance work makes up $3 \%$ of expenses and administration costs comprise $14 \%$.

Since expenses were so much lower than budgeted due to the suspension of many activities such as staff, committee, and board travel, at the end of last year we were able to make an investment in Atla's future. $\$ 100,000$ from product revenue was contributed to the Endowment Fund. As of mid-June, the current balance in the Endowment Fund was \$1.19 million, which met the Endowment Committee's short-term goal of $\$ 1$ million.

At the end of a fiscal year, we often add to the operating reserve. Going into fiscal year 2021, however, we maintained the same level of operating reserve since our cost to operate decreased due to the change in office space. The operating reserve is a fund mandated by the Board of Directors to cover unforeseen expenses, unexpected capital expenditures and to take advantage of unexpected opportunities. As dictated by the board's Investment Policy, the operating reserve must be maintained at a level between three to six months of monthly operating cost. For fiscal year 2021, it again stands at $\$ 2.3$ million, equal to 4.84 months of operating cost. If you'd like to know more about Atla's finances during 2019-2020, our audited fiscal year 2020 financial statements are available online in the Annual Report.

As of the end of May 2021, we are three-quarters of the way through fiscal year 2021. Like all of you, we have been concerned about the impact of COVID-19 on theological education and higher 
education in general. As a result, we budgeted very conservatively. We set a breakeven budget of $\$ 8,257,323$ and expect that there will be a decline in revenue from products and membership dues. Little or no travel is expected before the end of the year. Like some of your institutions, we did receive a Small Business Administration Paycheck Protection Program (PPP) Loan that was fully forgiven, so we have been able to treat that as revenue. The switch to new office space did reduce our lease expense, but only for the second half of the year, and we had to budget for the expenses associated with downsizing and moving. But midway through the year, I am pleased to report that we are right on track with the budget and expect to end the year in the black.

\section{ACTIVITY HIGHLIGHTS}

Atla and the Professional Development Committee joined our peer library consortia in the International Coalition of Library Consortia (ICOLC) to form the Professional Development Alliance (PDA). The PDA is dedicated to sharing professional development opportunities among ICOLC member consortia. This new initiative multiplies the number and variety of online professional development opportunities available to Atla member libraries.

The Committee on Diversity, Equity and Inclusion (DEI) awarded two Atla Diversity Scholarships last year and the 2021 scholarship recipients will be announced soon. These $\$ 4,000$ scholarships are funded by the Atla Scholarships \& Grants Annual Fund, which is sustained through the donations of Atla members and through a generous annual gift from EBSCO.

The Scholarly Communication Committee initiated a new grant program to support the creation of open educational resources (OER) in religion and theology. Two OER grants were awarded last year and additional grants will be awarded in 2021.

Atla continued its long-term investment in open access. Since last year's conference, Atla Open Press published three exciting new books. Volume 1 of the series Women in Religion, Claiming Notability for Women Activists in Religion, was done in collaboration with the Women's Caucus of AAR. ATS Women in Leadership: Celebrating Twenty Years, was created with ATS, and Preserving the Past and Engaging the Future: Theology \& Religion in American Special Collections is a collection of essays edited by M. Patrick Graham. 


\section{MEMBERSHIP DUES FOR 2021-2022}

At Atla, we remain concerned about the wellbeing of our members. Atla itself appears to have successfully weathered the worst of the turmoil that COVID-19 caused, but we know that the pandemic is continuing to have a significant impact on many Atla members. As you know all too well, this financial stress has manifested itself in budget cuts, layoffs, furloughs, or eliminated positions. We were pleased to offer significantly reduced registration fees for members to attend Atla Annual 2021 Online - and that modest registration fee was mostly offset with travel grants. But we wanted to do more. At their regular meeting on June 15, the Atla Board of Directors authorized Atla to continue to offer members financial relief through optional dues reduction for fiscal year 2022. At the point of renewal, individual members may pay their regular dues amount, or choose from several discounts $(25 \%, 50 \%, 75 \%$, or $100 \%)$. Institutional members may choose to pay their regular dues or take a standard discount (25\%). These rates are also available to new members. This is Atla's way of helping our members through these continuing trying times by ensuring they still have access to the full benefits of Atla membership.

It is already clear that while the overall economic environment has shown signs of improvement, the coming year will continue to be fraught with unexpected challenges. But I'm optimistic that ample opportunities exist to make progress on moving forward with Atla's Organizational Ends and our ongoing purpose: To promote worldwide scholarly communication in religion and theology by advancing the work of libraries and related information providers. Together we can succeed in the midst of any challenges the world tosses our way.

\section{FURTHER READING}

2020 Annual Report: https://www.atla.com/blog/annual-report-fy20/

International Coalition of Library Consortia: https://icolc.net/

Committee on Diversity, Equity, and Inclusion: https://www.atla. com/about/dei/

Scholarly Communication Committee: https://www.atla.com/about/ scholarly-communication-committee/ 
"Atla Announces Award of Grants to Fund Creation of OER": https:// www.atla.com/blog/atla-awards-oer-grants/

Books@Atla Open Press: https://books.atla.com/atlapress 